\title{
Pengaruh Store Atmosphere terhadap Minat Beli Konsumen (Studi pada Distro-Distro di Mataram)
}

\author{
Rian Indranopa \\ rian.indranopa@gmail.com \\ Universitas Teknologi Mataram \\ Agus Hermanto \\ agushermanto2511@gmail.com \\ Universitas Teknologi Mataram
}

\begin{abstract}
Abstrak
Pokok permasalahan dalam penelitian ini adalah apakah store atmosphere yang terdiri dari exterior, general interior, store layout, dan interior display mempunyai pengaruh signifikan secara parsial dan simultan terhadap minat beli konsumen pada distro-distro di Mataram? Dan variabel manakah yang berpengaruh dominan terhadap minat beli konsumen pada distro-distro di Mataram?. Tujuan penelitian ini adalah untuk mengetahui bagaimana Pengaruh Store AtmosphereTerhadap Minat Beli Konsumen. Jenis penelitian yang akan dilakukan bersifat asosiatif kausal dengan jumlah responden sebanyak 160 orang responden. Untuk menganalisis pengaruh store atmosphere digunakan Uji Asumsi Klasik, Analisis Regresi Linier Berganda dan Koefisien Determinasi Berganda $\left(R^{2}\right)$. Adapaun pembaharuan dari penelitian terdahulu yang digubnakan dalam penelitian ini meliputi; pembaharuan variable devenden dan indevenden, analisis data dan jumlah responden yang digunakan.

Secara umum semua variabel independen pada penelitian ini berpengaruh namun tidak signifikan terhadap minat beli konsumen pada distro-distro di Mataram. Hal ini dikarenakan responden tidak begitu memperhatikan setiap variabel berkaitan dengan store atmosphere secara terpisah, karena store atmosphere itu sendiri merupakan satu kesatuan yang utuh. Dari hasil penelitian, dapat disimpulkan bahwa Variabel store layput dan interior displayberpengaruh signifikan terhadap minat beli konusmenpada distro-distro di Mataram. Saran untuk pebneliti selanjutnya yaitu peneliti memperhatikan variabel exterior (bagian luar toko) yang terdiri dari papan nama toko, desain bangunan toko dan lingkungan sekitar dan vaariabel general interior (bagian dalam toko) yang terdiri dari pencahayaan, pendinginu adara dan kebersihanserta store layout (tata letak toko) yang terdiri dari penataan barang, jenis pakaian dan fasilitas toko.
\end{abstract}

Kata kunci : store atmosphere, minat beli konsumen

\section{Pendahuluan}

Pada masa ini dunia usaha memasuki era globalisasi yang memberikan peluang dan tantangan bisnis bagi perusahaan yang beroperasi di Indonesia. Dimana keadaan tersebut memunculkan persaingan yang semakin ketat antar perusahaan, hali ini juga terjadi pada usaha konveksi yang saat ini mengalami perkembangan cukup pesat. Dengan kondisi tersebut, maka peran aspek pemasaran sangat menunjang daya saing perusahaan dalam mengantisipasi persaingan tersebut, utamanya dalam tujuan memenuhi kebutuhan konsumen. Kegiatan pemasaran berorientasi pada pelanggan yang dilakukan oleh suatu perusahaan sangatlah menentukan keberhasilan usaha perushaan tersebut di masa yang akan datang (Zayyana, 2014).

Melihat kondisi persaingan yang semakin ketat, setiap bisnis konveksi perlu meningkatkan kekuatan yang ada dalam perusahaannya dengan cara memunculkan perbedaan atau keunikan yang dimiliki perusahaan dibandingkan dengan pesaing untuk dapat menarik minat beli konsumen. Minat beli merupakan suatu keinginan untuk membeli suatu produk atau jasa akibat pengaruh baik 
eksternal maupun internal dimana sebelumnya dilakukan evaluasi terhadap produk atau jasa yang akan dibeli. Sutisna dan Prawitra (2001:201) mengemukakan bahwa, minat beli merupakan sesuatu yang berhubungan dengan rencana konsumen untuk membeli produk tertentu serta berapa banyak unit produk yang dibutuhkan pada periode tertentu.

Bisnis yang dijalankan dewasa ini tidak lagi berorientasi pada keuntungan semata. Pemasaran aktif yang lebih berorientasi pada pelanggan lebih banyak digunakan oleh para pelaku bisnis, meskipun hal ini mengharuskan para pelaku bisnis tersebut untuk mendefinisikan "keinginan \& kebutuhan" dari sudut pandang konsumen. Harga, kualitas dan pelayanan tidak lagi menjadi bahan pertimbangan utama bagi para konsumen, saat ini store atmosphere (suasana toko) menjadi faktor penting. Hal ini diperkuat dengan pernyataan dari Gillani (2012)(Gillani, 2012) dalam Bayu (2013:518) di dalam bisnis yang kompetitif saat ini pasar telah berkonsentrasi pada semua aspek lain, store atmosphere telah dianggap penting sebagai titik pembelian bagi pelanggan.

Menurut Berman dan Evans (2008) dalam Alma (2011:61) unsur-unsur store atmosphere sebagai berikut :

a. Exterior (bagian depan toko)

b. General Interior (bagian dalam toko)

c. Store Layout (tata letak toko)

d. Interior Display (dekorasi pemikat dalam toko)

Pada intinya store atmosphere harus mampu memberikan kepuasan tersendiri bagi konsumen dalam melakukan pembelian. Bagi konsumen suasana nyaman menjadi bahan pertimbangan sendiri sebelum memutuskan untuk datang atau mengunjungi toko tertentu. Oleh karena itu perubahan terhadap store atmosphere harus selalu dirancang agar tidak membosankan sehingga pelanggan tetap setia dan perusahaan dapat mengatasi para pesaing. Jika konsumen bosan dengan suasana toko yang mereka kunjungi, kemungkinan besar mereka akan beralih ke toko lain, sehingga para pelaku bisnis menerapkan berbagai cara yang efektif dalam menciptakan suasana toko yang menarik dengan tujuan untuk menang dalam persaingan.

Persaingan distro semakin ketat khususnya di Mataram Lombok-NTB. Misalnya, Distro Three Second, Distro Lovely Sunday, Distro G-CO, dan Distro Kickdenim. Distro-distro ini merupakan pelaku bisnis dalam bidang pakaian yang berkembang dan menawarkan produk yang tidak kalah menarik satu dengan yang lainnya, dengan tujuan untuk merebut hati konsumen dalam melakukan pembelian.

Jumlah remaja di kota Mataram yaitu sebanyak 130.856 orang, ini menjadi potensi yang besar sebagai target pasar distro-distro di Mataram (BPS Kota Mataram). Selain itu, dari wawancara dan pengamatan awal peneliti kepada pihak distro menyebutkan bahwa pengunjung yang datang dari luar Kota Mataram berkisar antara 15\% sampai dengan 25\% dari jumlah remaja yang ada di Kota Mataram.

Menghadapi persaingan bisnis dalam merebut hati konsumen untuk melakukan pembelian, salah satu strategi pemasaran yang diterapkan oleh distro adalah memperhatikan suasana toko (store atmosphere)yang menjadi ciri khas tersendiri antara distro satu dengan distro lainnya, semua ingin menampilkan identitasnya masing-masing. Yang menjadi hal yang menarik lagi ketika berkunjung ke salah satu distro adalah penataan tempat, barang maupun tata cahaya yang di setting dengan sangat menarik. Lokasi distro yang kebanyakan tidak terlalu besar dan luas bisa disulap menjadi tempat berbelanja busana yang sangat nyaman untuk para calon pembeli yang berkunjung dengan variasi warna yang menarik untuk memberi kenyamanan setiap orang yang datang untuk membeli atau sekedar mencari tahu tren busana anak muda jaman sekarang. Sepatu, baju, kaos, sabuk, dompet, topi dan lain-lain di jual dengan harga yang disesuaikan dengan isi dompet remaja. Inilah yang membuat ketatnya persaingan antar distro di Mataram. 


\section{Tinjauan Pustaka}

\subsection{Store Atmosphere (Suasana Toko)}

Store atmosphere dapat dikatakan sebagai kegiatan pemasaran yang dapat memberikan kesan kepada konsumen melalui suasana toko yang diberikan. Kesan positif dari konsumen akan timbul apabila suasana toko yang diberikan oleh perusahaan kepada konsumen memberikan kenyamanan di dalam toko, sehingga konsumen betah dalam berbelanja di toko tersebut. Dan sebaliknya apabila suasana toko yang diberikan tidak nyaman maka cenderung konsumen akan malas untuk berbelanja pada toko tersebut.

Menurut Lamb, hair, McDaniel (2001:105) Store atmosphere yaitu kesan keseluruhan yang disampaikan oleh tata letak fisik toko, dekorasi, dan lingkungan sekitarnya.Gilbert dalam Foster (2008:61) menjelaskan bahwa atmosphere tokomerupakan kombinasi dari pesan secara fisik yang telah direncanakan, atmosphere toko dapat digambarkan sebagai perubahan terhadap perancangan lingkungan pembelian yang menghasilkan efek emosional khusus yang dapat menyebabkan konsumen melakukan tindakan pembelian.

Dari beberapa definisi di atas dapat disimpulkan bahwa store atmosphere (suasana toko) merupakan kesan yang ingin disampaikan oleh perusahaan kepada konsumen melalui tampilan interior, eksterior, tata letak, lalu lintas internal toko, kenyamanan, udara, layanan, musik, seragam pramuniaga, pajangan barang dan sebagainya agar konsumen merasa nyaman dan melakukan tindakan pembelian.

Berikut ini adalah faktor-faktor yang paling berpengaruh dalam menciptakan suasana toko menurut Lamb, Hair, McDaniel (2001:108-109) sebagai berikut :

a. Jenis Karyawan dan kepadatan : jenis karyawan mengacu pada karakteristik umum karyawan-sebagai contoh, rapi, ramah, berwawasan luas, dan berorientasi pada pelayanan.

b. Jenis barang dagangan dan kepadatan : jenis barang dagangan yang dijual dan bagaimana barang tersebut dipajang menentukan suasana yang ingin diciptakan oleh pengecer.

c. Jenis perlengkapan tetap (fixture) dan kepadatan : perlengkapan tetap bisa elegan (terbuat dari kayu Jati), trendi (dari krom atau kaca tidak tembus pandang), atau terdiri dari mejameja kuno seperti di toko antik.

d. Bunyi suara : bunyi suara bisa menyenangkan atau menjengkelkan bagi seorang pelanggan.

e. Aroma : bau bisa merangsang maupun mengganggu penjualan.

f. Factor visual : warna dapat menciptakan suasana hati atau memfokuskan perhatian dan oleh karena itu menjadi faktor penting dalam usaha.

Menurut Alma (Alma, 2011) perubahan terhadap atmosphere toko harus selalu dirancang agar tidak membosankan, langganan tetap setia, dan mengatasi para saingan. Jika konsumen bosan dengan suasana toko kemungkinan besar mereka akan beralih ke toko lain. beberapa ciri dari store atmosphere ialah sebagai berikut:

a. Eksterior Toko, meliputi meliputi keseluruhan bangunan fisik yang dapat di lihat dari luar, bentuk bangunan, warna dan model. Desain eksterior merupakan bagian fisik yang berperan kepada konsumen untuk membayangkan seperti apa toko yang akan mereka masuki.

b. Bagian depan toko, ini harus ditata dengan rapi, indah, dan mengesankan calon konsumen. Bagian depan toko ini merupakan bagian penting yang mendapat sorotan pertama, dan menimbulkan daya tarik tersendiri agar konsumen tergerak masuk ke dalam toko.

c. Etalase, ini harus menarik, barang dipajang secara beraturan dan rapi, serasi warna dan bentuknya.

d. Suasana sekeliling toko, apakah banyak toko lain atau tidak. Apabila banyak toko lain, ini dapat berakibat akan muncul kanibalisme atau sinergi. Kanibalisme artinya satu toko dengan toko yang lain saling mematikan karena faktor persaingan. Namun kebanyakan komplek pertokoan menjadi suatu sinergi saling melengkapi diantara toko sekelilingnya, dan menimbulkan keuntungan berupa daya tarik dari masyarakat berkunjung ke pusat 
bisnis tersebut. Ini sangat tergantung pada pihak manajemen, apaka ia dapat mengambil manfaat dari banyaknya toko lain disekeliling tokonya.

e. Sarana parkir, apakah tersedia cukup lahan, keteraturandan keamanan parkir. Apakah gratis, atau ditarik sewa parkir jam-jaman dsb.

f. Unsur interior, ini menyangkut banyak hal seperti desain, estetika, penerangan, warna, lalu lintas internal, sirkulasi udara,kebersihan, kesejukan, tata letak, pengelompokan produk, arah/penunjuk, dan lokasi kasir.

Menurut Barry dan Evans dalam (Meldarianda \& Lisan S, 2010), "Atmosphere can be divided into several elements: exterior, general interior, store layout, and displays." Cakupan Store atmosphere ini meliputi : bagian luar toko, bagian dalam toko, tata letak ruangan, dan pajangan (interior point of interest display),akan dijelaskan lebih lanjut dibawah ini:

a. Exterior (Bagian Luar Toko)

Karakteristik exterior mempunyai pangaruh yang kuat pada citra toko tersebut, sehingga harus direncanakan dengan sebaik mungkin. Kombinasi dari exterior ini dapat membuat bagian luar toko menjadi terlihat unik, menarik, menonjol dan mengundang orang untuk masuk kedalam toko. Elemen-elemen exterior ini terdiri dari sub elemen-sub elemen sebagai berikut:

1) Storefront (Bagian Muka Toko)

Bagian muka atau depan toko meliputi kombinasi papan nama, pintu masuk, dan konstruksi bangunan. Storefront harus mencerminkan keunikan, kemantapan, kekokohan atau hal-hal lain yang sesuai dengan citra toko tersebut. Khususnya konsumen yang baru sering menilai toko dari penampilan luarnya terlebih dahulu sehinggaexterior merupakan faktor penting untuk mempengaruhi konsumen untuk mengunjungi toko.

2) Marquee (Simbol)

Marquee adalah suatu tanda yang digunakan untuk memajang nama atau logo suatu toko. Marquee dapat dibuat dengan teknik pewarnaan, penulisan huruf, atau penggunaan lampu neon. Marquee dapat terdiri dari nama atau logo saja, atau dikombinasikan dengan slogan dan informasi lainya. Supaya efektif, marquee harus diletakan diluar, terlihat berbeda, dan lebih menarik atau mencolok daripada toko lain disekitarnya.

3) Entrance (Pintu Masuk)

Pintu masuk harus direncanakan sebaik mungkin, sehingga dapat mengundang konsumen untuk masuk melihat ke dalam toko dan juga mengurangi kemacetan lalu lintas keluar masuk konsumen.

b. General Interior (Bagian Dalam Toko)

Yang paling utama yang dapat membuat penjualan setelah pembeli berada di toko adalah display. Desain interior dari suatu toko harus dirancang untuk memaksimalkan visual merchandising.Display yang baik yaitu yang dapat menarik perhatian pengunjung dan membantu meraka agar mudah mengamati, memeriksa, dan memilih barang dan akhirnya melakukan pembelian. Ada banyak hal yang akan mempengaruhi persepsi konsumen pada toko tersebut. Menurut Barry dan Evans (2004), elemen-elemen general interior terdiri dari:

1) Flooring (Lantai)

Penentuan jenis lantai, ukuran, desain dan warna lantai sangat penting, karena konsumen dapat mengembangkan persepsi mereka berdasarkan apa yang mereka lihat.

2) Color and Lightening (Warna dan Pencahayaan)

Setiap toko harus mempunyai pencahayaan yang cukup untuk mengarahkan atau menarik perhatian konsumen ke daerah tertentu dari toko. Konsumen yang berkunjung akan tertarik pada sesuatu yang paling terang yang berada dalam pandangan mereka. Tata cahaya yang baik mempunyai kualitas dan warna yang dapat membuat suasana 
yang ditawarkan terlihat lebih menarik, terlihat berbeda bila dibandingkan dengan keadaan yang sebenarnya.

3) Scent and Sound (Aroma dan Musik)

Tidak semua toko memberikan pelayanan ini, tetapi jika layanan ini dilakukan akan memberikan suasana yang lebih santai pada konsumen, khusunya konsumen yang ingin menikmati suasana yang santai dengan menghilangkan kejenuhan, kebosanan, maupun stress sambil menikmati makanan.

4) Fixture (Penempatan)

Memilih peralatan penunjang dan cara penempatan meja harus dilakukan dengan baik agar didapat hasil yang sesuai dengan keinginan. Karena penempatan meja yang sesuai dan nyaman dapat menciptakan image yang berbeda pula.

c. Layout Ruangan (Tata Letak Toko)

Pengelola toko harus mempunyai rencana dalam penentuan lokasi dan fasilitas toko.Pengelola toko juga harus memanfaatkan ruangan toko yang ada seefektif mungkin. Halhal yang perlu diperhatikan dalam merancang layout adalah sebagai berikut:

1) Allocation of floor space for selling, personnel, and customers.

Dalam suatu toko, ruangan yang ada harus dialokasikan untuk:

- Selling Space (Ruangan Penjualan)

Ruangan untuk menempatkan dan tempat berinteraksi antara konsumen dan pramusaji.

- Personnel Space (Ruangan Pegawai)

Ruangan yang disediakan untuk memenuhi kebutuhan pramusaji seperti tempat beristirahat atau makan.

- Customers Space (Ruangan Pelanggan)

Ruangan yang disediakan untuk meningkatkan kenyamanan konsumen seperti toilet, ruang tunggu.

2) Traffic Flow (Arus Lalu Lintas)

Macam-macam penentuan arus lalu lintas toko, yaitu:

- $\quad$ Grid Layout (Pola Lurus)

Penempatan fixture dalam satu lorong utama yang panjang.

- Loop/Racetrack Layout (Pola Memutar)

Terdiri dari gang utama yang dimulai dari pintu masuk, mengelilingi seluruh ruangan, dan biasanya berbentuk lingkaran atau persegi, kemudian kembali ke pintu masuk.

- Spine Layout (Pola Berlawanan Arah)

Pada spine layout gang utama terbentang dari depan sampai belakang tok membawa pengunjung dalam dua arah.

- Free-flow Layout (Pola Arus Bebas)

Pola yang paling sederhana dimana fixture dan barang-barang diletakan dengan bebas.

d. Interior Point of Interest Display (Dekorasi Pemikat Dalam Toko)

Interior point of interest display mempunyai dua tujuan, yaitu memberikan informasi kepada konsumen dan menambah store atmosphere, hal ini dapat meningkatkan penjualan dan laba toko. Interior point of interest display terdiri dari :

1) Theme Setting Display (Dekorasi Sesuai Tema)

Dalam suatu musim tertentu retailer dapat mendisain dekorasi toko atau meminta pramusaji berpakaian sesuai tema tertentu.

2) Wall Decoration (Dekorasi Ruangan)

Dekorasi ruangan pada tembok bisa merupakan kombinasi dari gambar atau poster yang ditempel, warna tembok, dan sebagainya yang dapat meningkatkan suasana toko. 


\subsection{Minat Beli Konsumen}

Pengertian minat beli konsumen menurut Kotler (2005:205) adalah sesuatu yang timbul setelah menerima rangsangan dari produk yang dilihatnya, dari sana timbul ketertarikan untuk mencoba produk tersebut sampai pada akhirnya timbul keinginan untuk membeli agar dapat memilikinya.Menurut Assael (2002:53) menyatakan bahwa:"Minat beli konsumen timbul dan terbentuk setelah konsumen melakukan evaluasi terlebih dahulu terhadap suatu merek dan akan melakukan pembelian terhadap merek yang dapat memberikan tingkat paling tinggi dari kepuasan yang diharapkan".

Minat beli timbul setelah konsumen menerima stimulus dari sesuatu yang dilihat. Pada saat konsumen memasuki toko tersebut, saat itulah timbul perhatian, keterkaitan, keingintahuan, bahkan keinginan untuk mencoba dan kemudian ingin membeli produk tersebut. Assael (2002:60) menjelaskan bahwa titik tolak untuk memahami perilaku pembelian konsumen adalah melakukan model stimulasi AIDA yang berusahan menggambarkan tahap-tahap suatu rangsangan tertentu yang diberikan oleh para pemasar, yaitu sebagai berikut:

a. Attention, yaitu timbulnya perhatian konsumen terhadap suatu usaha pemasaran yang diberikan oleh pemasar.

b. Interest, yatu munculnya minat beli konsumen tertarik terhadap objek yang dikenalkan oleh suatu pemasar

c. Desire, yaitu setelah merasa tertarik, timbul hasrat atau keinginan untuk memiliki objek tersebut.

d. Action, yaitu tindakan yang muncul setelah tiga tahapan diatas, yaitu melakukan pembelian.

Minat beli konsumen merupakan masalah yang sangat kompleks namun harus tetap menjadi perhatian pemasar. Minat konsumen untuk membeli dapat muncul sebagai akibat dari adanya rangsangan (stimulus) yang ditawarkan oleh perusahaan. Masing-masing stimulus tersebut dirancang untuk menghasilkan tindakan pembelian konsumen.

\subsection{Hubungan antara Store Atmosphere dengan Minat Beli Konsumen.}

Store Atmosphere yang didesain secara tepat dan baik akan dapat mendorong konsumen untuk mau memasuki toko tersebut dan kemudian melakukan pembelian. Unsur-unsur pendukung dari Store Atmosphere yang mencangkup store exterior, general interior, store layout, dan interior display. Kesemuanya akan terintegrasi membentuk suatu citra atau image toko yang diharapkan (Berman \& Evan, 1992). Citra toko ini menimbulkan persepsi di mata pengunjung dan dapat menjadi stimuli untuk masuk ke dalam toko, yang berlanjut pada proses interaksi hingga pembelian. Karena penting bagi semua pihak terkait untuk memahami dengan objek toko maupun citra yang diinginkan agar desain yang dihasilkan bukan hanya sekedar desain yang menarik namun ideal dan dapat menjual. Store atmosphere tersebut dapat memberikan persepsi terhadap masyarakat yang pada akhirnya menimbukan respon dan menciptakan kenyamanan bagi konsumen pada saat menikmati suasana di dalam toko.

Elemen-elemen dari penataan Store atmosphere seringkali mempengaruhi proses pemilihan toko dan minat beli konsumen. Penciptaan store atmosphere yang baik melalui variabel-variabel store atmosphere yang meliputi store exterior, general interior, store layout, dan interior display. Persepsi terhadap Store exterior diharapkan memiliki pengaruh terhadap pengenalan store tersebut serta menarik konsumen untuk berkunjung. Persepsi terhadap General interior difungsikan untuk memberikan kesan aman dan nyaman saat berbelanja. Persepsi terhadap Store layout diharapkan berpengaruh terhadap fasilitas kemudahan dalam berbelanja. Sedangkan persepsi terhadap Interior display diharapkan berpengaruh terhadap suasana lingkungan toko dengan tujuan meningkatkan penjualan toko. Store atmosphere tidak hanya memberikan nilai tambah bagi produk yang dijual tetapi juga menciptakan suasana lingkungan pembelian yang menyenangkan bagi konsumen. 


\section{Kerangka Konseptual}

Dalam memenuhi kebutuhan dan keinginannya, konsumen biasanya memutuskan pembelian berdasarkan pemilihan alternatif atau pertimbangan-pertimbangan yang dilakukan sebelum melakukan pembelian terhadap suatu barang dan jasa. Salah satu pertimbangan konsumen dalam berbelanja adalah berdasarkan store atmosphere.

Dalam kerangka konseptual inilah peneliti ingin mengetahui tentang pengaruh store atmosphere yang terdiri dari exterior, general interior, store layout, dan interior display dan pengaruhnyaterhadap minat beli konsumen. Adapun kerangka konseptual dalam penelitian ini digambarkan sebagai berikut :
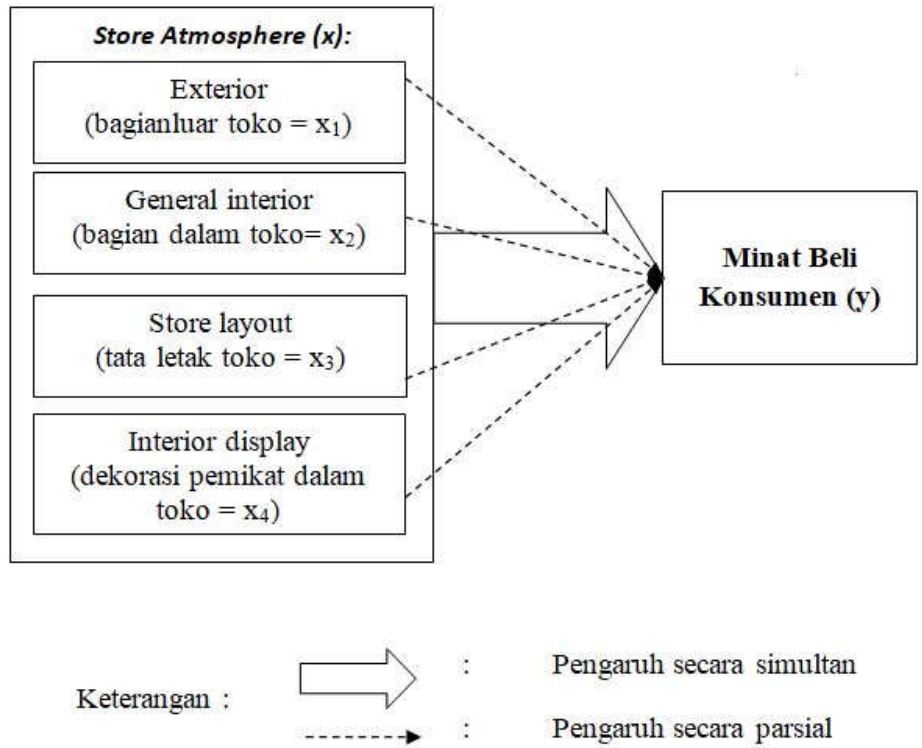

\section{Gambar 1 Kerangka Konseptual}

\section{Metode Penelitian}

Metode pengumpulan data yang digunakan dalam penelitian ini adalah metode sample survey. Menurut Nazir (2005:217) sample survey adalah suatu prosedur dimana hanya sebagian populasi saja yang diambil dan digunakan untuk menentukan sifat serta ciri yang dikehendaki dari populasi.Populasi dalam penelitian ini adalah siapa saja yang berkunjung distro-distro di Mataram. Dalam hal ini peneliti mengambil sampel sebanyak 160 responden, jumlah sampel tersebut juga telah memenuhi persyaratan penarikan sampel yang disarankan yaitu 5-10 kali jumlah item pertanyaan yang terdapat pada kuesioner (Ghozali dan Fuad, 2005). Berdasarkan jumlah item pertanyaan dalam penelitian ini adalah 16 pertanyaan, dengan demikian jumlah sampel adalah $10 \mathrm{x}$ $16=160$ orang.

Penentuan sampel menggunakan non probabilitas, di mana jumlah populasi tidak diketahui yakni sebagian kecil pengunjung yang berbelanja. Teknik yang digunakan dalam menentukan unit sampel yakni dengan menggunakan teknik Sampling Insidental adalah teknik penentuan sampel berdasarkan kebetulan, yaitu siapa saja yang secara kebetulan/insidental bertemu dengan peneliti dapat digunakan sebagai sampel, bila dipandang orang yang kebetulan ditemui itu cocok sebagai sumber data (Sugiyono, 2010)(Sugiyono, 2010).Teknik pengumpulan data yang digunakan dalam penelitian ini adalah wawancara, dokumentasi dan angket. Alat pengumpulan data yang digunakan adalah koesioner.Tahapan prosedur pengumpulan data antara lain: skala likert. uji validitas dan reliabilitas. 


\section{Analisis Data dan Pembahasan}

\subsection{Analisis Data}

Prosedur Analisis Data yang digunakan pada penelitian ini yaitu: 1). Uji Asumsi Klasik, Sumodiningrat (2002:281) mengartikan uji asumsi klasik sebagai uji yang dilakukan untuk menguji asumsi regresi klasik. Uji asumsi klasik yang akan digunakan adalah uji normalitas, uji multikolinearitas, uji heteroskedastisitas dan uji Autokorelasi; 2). Uji Hipotesis terdiri dari; Uji t, Uji F dankoefisien Determinasi Berganda $\left(\mathrm{R}^{2}\right)$.

\subsection{Pembahasan}

5.2.1. Klasifikasi Responden Berdasarkan Alamat Responden

Berdasarkan hasil penelitian yang telah dilakukan, maka klasifikasi responden menurut alamat responden dapat diidentifikasikan sebagai berikut :

Tabel 1. Data Responden Berdasarkan Alamat

\begin{tabular}{|c|l|r|r|}
\hline No & \multicolumn{1}{|c|}{ Alamat } & Frekuensi (Orang) & Persentase (\%) \\
\hline 1 & Kota Mataram & 61 & 38,1 \\
\hline 2 & Lombok Barat & 21 & 13,1 \\
\hline 3 & Lombok Tengah & 30 & 18,8 \\
\hline 4 & Lombok Timur & 27 & 16,9 \\
\hline 5 & Lombok Utara & 6 & 3,8 \\
\hline 6 & Sumbawa & 9 & 5,6 \\
\hline 7 & Bima & 4 & 2,5 \\
\hline 8 & Dompu & 2 & 1,3 \\
\hline & Jumlah & $\mathbf{1 6 0}$ & $\mathbf{1 0 0}$ \\
\hline
\end{tabular}

Berdasarkan tabel di atas dapat diketahui bahwa sebagian besar responden beralamatkan di Kota Mataram yakni sebesar 38,1\%, sisanya beralamatkan di Lombok Barat sebesar 13,1\%, beralamatkan di Lombok Tengah sebesar 18,8\%, beralamatkan di Lombok Timur sebesar 16,9\%, beralamatkan di Lombok Utara sebesar 3,8\%, beralamatkan di Sumbawa sebesar 5,6\%, beralam di Bima 2,5\% dan beralamatkan di Dompu sebesar 1,3\%. Data tersebut menunjukan bahwa responden didominasi berasal dari Kota Mataram, hal ini disebabkan karena lokasi dari distro-distro tersebut berada di Kota Mataram.

\subsubsection{Klasisikasi Responden Berdasarkan Usia}

Berdasarkan hasil tabulasi menurut usia, responden dalam penelitian ini dapat diklasifikasikan sebagai berikut :

Tabel 2. Data Responden Berdasarkan Tingkat Usia

\begin{tabular}{|l|l|r|r|}
\hline \multirow{2}{*}{ No } & Usia ( Tahun ) & Jumlah (Orang) & Persentase (\%) \\
\hline 1 & $15-20$ & 16 & 10,0 \\
\hline 2 & $21-25$ & 135 & 84,4 \\
\hline 3 & $26-30$ & 9 & 5,6 \\
\hline \multicolumn{2}{|c|}{ Jumlah } & $\mathbf{1 6 0}$ & $\mathbf{1 0 0}$ \\
\hline
\end{tabular}


Berdasarkan tabel di atas, dapat diketahui bahwa sebagian besar responden berusia antara 21-25 tahun yaitu sebesar 84,4\%, sisanya responden yang berusia antara 15-20 tahun yaitu sebesar $10,0 \%$ dan responden yang berusia antara 26-30 tahun yaitu sebesar 5,6\%. Hal ini menunjukkan bahwa responden terbanyak yaitu responden yang berusia antara 21-25 tahun, karena pada usia tersebut mereka dituntut untuk memenuhi keinginan untuk selalu tampil gaya.

\subsubsection{Klasifikasi Responden Berdasarkan Jenis Kelamin}

Berdasarkan hasil penelitian yang telah dilakukan, maka klasifikasi responden menurut jenis kelamin dapat diidentifikasikan sebagai berikut :

Tabel 3. Data Responden Berdasarkan Jenis Kelamin

\begin{tabular}{|l|l|r|r|}
\hline No & Jenis Kelamin & Jumlah (Orang) & Persentase (\%) \\
\hline 1 & Pria & 112 & 70,0 \\
\hline 2 & Wanita & 48 & 30,0 \\
\hline \multicolumn{2}{|c|}{ Jumlah } & $\mathbf{1 6 0}$ & $\mathbf{1 0 0}$ \\
\hline
\end{tabular}

Berdasarkan tabel di atas, dapat diketahui bahwa sebagian besar responden adalah responden yang berjenis kelamin wanita yaitu sebesar $70,0 \%$ dan sisanya responden yang berjenis kelamin pria yaitu sebesar 30,0\%. Hal ini menunjukkan bahwa responden yang berjenis kelamin pria lebih banyak dibandingkan degan responden yang berjenis kelamin wanita, karena pada umumnya distro-distro lebih banyak menyediakan jenis produk untuk pria dibandingkan jenis produk untuk wanita.

\subsubsection{Klasifikasi Responden Berdasarkan Tingkat Pendidikan}

Berdasarkan tingkat pendidikan yang ditempuh, maka responden dalam penelitian ini dapat diklasifikasikan seperti pada tabel berikut ini :

Tabel 4. Data Responden Berdasarkan Tingkat Pendidikan

\begin{tabular}{|c|l|r|r|}
\hline No & Pendidikan & \multicolumn{1}{c|}{ Jumlah (Orang) } & Persentase (\%) \\
\hline 1 & SLTP & 17 & 10,6 \\
\hline 2 & SMA & 118 & 73,8 \\
\hline 3 & D3 & 21 & 2,5 \\
\hline 4 & S1 & $\mathbf{1 6 0}$ & 13,1 \\
\hline \multicolumn{2}{|c|}{ Jumlah } & $\mathbf{1 0 0}$ \\
\hline
\end{tabular}

Dari tabel di atas menunjukkan bahwa sebagian besar responden memiliki pendidikan terakhir SMA yaitu sebesar 73,8\%, sisanya responden yang memiliki pendidikan terakhir SLTP yaitu sebesar 10,6\%, responden yang memiliki pendidikan terakhir D3 yaitu sebesar 2,5\%, dan responden yang memiliki pendidikan terakhir S1 sebesar yaitu 13,1\%. Dari data tersebut terlihat bahwa responden yang paling banyak yaitu didominasi oleh responden yang memiliki pendidikan terakhir SMA.

\subsubsection{Klasifikasi Responden Berdasarkan Jenis Pekerjaan}

Berdasarkan jenis pekerjaannya, responden dalam penelitian ini dapat diklasifikasikan sebagai berikut :

Tabel 5. Data Responden Berdasarkan Pekerjaan

\begin{tabular}{|l|l|r|r|}
\hline No & Jenis Pekerjaan & Jumlah (Orang) & Persentase (\%) \\
\hline 1 & Pelajar & 17 & 10,6 \\
\hline 2 & Mahasiswa & 115 & 71,9 \\
\hline 3 & Swasta & 23 & 14,4 \\
\hline 4 & PNS & 5 & 3,1 \\
\hline \multicolumn{2}{|c|}{ Jumlah } & $\mathbf{1 6 0}$ & $\mathbf{1 0 0}$ \\
\hline
\end{tabular}


Berdasarkan tabel di atas menunjukkan bahwa sebagian besar responden yang memiliki pekerjaan sebagai mahasiswa yaitu sebesar $71,9 \%$, sisanya responden yang memiliki pekerjaan sebagai pelajar yaitu sebesar 10,6\%, responden yang memiliki pekerjaan sebagai swasta yaitu sebesar 14,4\% dan responden yang memiliki pekerjaan sebagai PNS yaitu sebesar 3,1\%. Dari data tersebut dapat diketahui bahwa responden didominasi oleh responden yang memiliki pekerjaan sebagai mahasiswa.

\subsection{Analisis Data}

\subsubsection{Uji Validitas}

Validitas/ketepataan digunakan untuk mengetahui kelayakan butir-butir dalam suatu item pertanyaan penelitian. Suatu item pertanyaan apabila memiliki nilai positif $>0.3$, maka item pertanyaan tersebut dinyatakan valid/tepat. Tabel berikut ini akan menyajikan nilai validitas. Data yang telah diperoleh dan diolah dengan bantuan program SPSS 16.0 for Windows.

\section{Tabel 6. Hasil Uji Validitas}

\begin{tabular}{|c|l|c|c|c|}
\hline Variabel & Pertanyaan & $\begin{array}{c}\text { Korelasi } \\
\text { Pearson }\end{array}$ & Nilai Kritis & Ket \\
\hline \multirow{3}{*}{ Exterior $\left(\mathbf{X}_{\mathbf{1}}\right)$} & Pertanyaan 1 & 0,631 & 0,3 & Valid \\
\cline { 2 - 5 } & Pertanyaan 2 & 0,513 & 0,3 & Valid \\
\cline { 2 - 5 } & Pertanyaan 3 & 0,453 & 0,3 & Valid \\
\hline \multirow{3}{*}{ General Interior $\left(\mathbf{X}_{\mathbf{2}}\right)$} & Pertanyaan 1 & 0,548 & 0,3 & Valid \\
\cline { 2 - 5 } & Pertanyaan 2 & 0,631 & 0,3 & Valid \\
\cline { 2 - 5 } Store Layout $\left(\mathbf{X}_{\mathbf{3}}\right)$ & Pertanyaan 3 & 0,377 & 0,3 & Valid \\
\hline \multirow{3}{*}{ Interior Display $\left(\mathbf{X}_{4}\right)$} & Pertanyaan 1 & 0,548 & 0,3 & Valid \\
\cline { 2 - 5 } & Pertanyaan 2 & 0,546 & 0,3 & Valid \\
\cline { 2 - 5 } & Pertanyaan 3 & 0,497 & 0,3 & Valid \\
\cline { 2 - 5 } & Pertanyaan 1 & 0,410 & 0,3 & Valid \\
\cline { 2 - 5 } Minat Beli Konsumyaan 2 & 0,349 & 0,3 & Valid \\
\hline \multirow{3}{*}{$(\mathbf{Y})$} & Pertanyaan 3 & 0,356 & 0,3 & Valid \\
\cline { 2 - 5 } & Pertanyaan 1 & 0,701 & 0,3 & Valid \\
\cline { 2 - 5 } & Pertanyaan 2 & 0,469 & 0,3 & Valid \\
\cline { 2 - 5 } & Pertanyaan 3 & 0,383 & 0,3 & Valid \\
\cline { 2 - 5 } & Pertanyaan 4 & 0,397 & 0,3 & Valid \\
\hline
\end{tabular}

Berdasarkan tabel di atas, hasil analisis validitas dapat diketahui bahwa korelasi Pearson > dari kriteria validitas yang diajukan yaitu 0,3, dengan demikian seluruh pernyataan kuisioner yang diajukan valid.

\subsubsection{Uji Reliabilitas}

Uji reliabilitas digunakan untuk mengukur konsistensi dari variabel pada instrumen. Butir pertanyaan pada variabel dalam suatu instrumen dikatakan reliabel atau terpercaya apabila jawaban responden adalah konsisten atau stabil dari waktu ke waktu. Suatu konstruk atau variabel dikatakan reliabel jika memberikan nilai Cronbach Alpha $\geq 0,60$. Adapun hasil uji reliabilitas dari instrumen yang digunakan dalam penelitian ini ialah sebagai berikut :

Tabel 7. Hasil Uji Reliabilitas

\begin{tabular}{|l|c|c|c|}
\hline \multicolumn{1}{|c|}{ Variabel } & $\begin{array}{c}\text { Cronbach } \\
\text { Alpha }\end{array}$ & Nilai Kritis & Keterangan \\
\hline Exterior $\left(\mathbf{X}_{\mathbf{1}}\right)$ & 0,621 & 0,6 & Reliabel \\
\hline General Interior $\left(\mathbf{X}_{\mathbf{2}}\right)$ & 0,668 & 0,6 & Reliabel \\
\hline Store Layout $\left(\mathbf{X}_{3}\right)$ & 0,608 & 0,6 & Reliabel \\
\hline Interior Display $\left(\mathbf{X}_{\mathbf{4}}\right)$ & 0,665 & 0,6 & Reliabel \\
\hline Keputusan Pembelian $(\mathbf{Y})$ & 0,625 & 0,6 & Reliabel \\
\hline
\end{tabular}


Berdasarkan data tabel di atas, hasil analisis realibilitas dapat diketahui bahwa nilai Cronbach Alpha > nilai kritis yang diajukan sebesar 0,6 jadi dapat disimpulkan bahwa data yang diajukan reliabel.

\subsubsection{Deskripsi Variabel Exterior $\left(\mathrm{X}_{1}\right)$}

Adapun rata-rata jawaban dari responden mengenai variabel Exterior (X1) dalam tabel penelitian berikut ini :

Tabel 8. Deskripsi Jawaban Responden pada Variabel Exterior

\begin{tabular}{|c|c|c|c|}
\hline Variabel & Item & Skor & Total Jawaban \\
\hline \multirow{24}{*}{ Exterior } & \multirow{5}{*}{$\begin{array}{c}\text { Papan Nama } \\
\text { Toko }\end{array}$} & Sangat baik & 45 \\
\hline & & Baik & 300 \\
\hline & & Cukup baik & 174 \\
\hline & & Tidak baik & 30 \\
\hline & & Sangat tidak baik & 3 \\
\hline & \multicolumn{2}{|c|}{ Jumlah } & 552 \\
\hline & \multicolumn{2}{|c|}{ Rata-Rata } & 3.5 \\
\hline & \multicolumn{2}{|c|}{ Keterangan } & Cukup Baik \\
\hline & \multirow{5}{*}{$\begin{array}{c}\text { Desain } \\
\text { Bangunan Luar } \\
\text { Toko }\end{array}$} & Sangat baik & 45 \\
\hline & & Baik & 308 \\
\hline & & Cukup baik & 177 \\
\hline & & Tidak baik & 26 \\
\hline & & Sangat tidak baik & 2 \\
\hline & \multicolumn{2}{|c|}{ Jumlah } & 558 \\
\hline & \multicolumn{2}{|c|}{ Rata-Rata } & 3.5 \\
\hline & \multicolumn{2}{|c|}{ Keterangan } & Cukup Baik \\
\hline & \multirow{5}{*}{$\begin{array}{l}\text { Lingkungan } \\
\text { Sekitar }\end{array}$} & Sangat baik & 75 \\
\hline & & Baik & 272 \\
\hline & & Cukup baik & 183 \\
\hline & & Tidak baik & 32 \\
\hline & & Sangat tidak baik & 0 \\
\hline & \multicolumn{2}{|c|}{ Jumlah } & 562 \\
\hline & \multicolumn{2}{|c|}{ Rata-Rata } & 3.5 \\
\hline & \multicolumn{2}{|c|}{ Keterangan } & Cukup Baik \\
\hline
\end{tabular}

Dari tabel di atas dapat diketahui bahwa rata-rata jawaban responden variabel exterior pada item papan nama toko sebesar 3,5 dengan keterangan cukup baik, pada item desain bangunan luar toko memiliki skor rata-ratasebesar 3,5 dengan keterangan cukup baik, dan pada item lingkungan sekitar memiliki skor rata-rata sebesar 3,5 dengan keterangan cukup baik, 


\subsubsection{Deskripsi Variabel General Interior $\left(\mathrm{X}_{2}\right)$}

Adapun jawaban dari responden mengenai variabel general interior (X2) dalam tabel penelitian berikut ini :

Tabel 9. Deskripsi Jawaban Responden pada Variabel General Interior

\begin{tabular}{|c|c|c|c|}
\hline Variabel & Item & Skor & Total Jawaban \\
\hline \multirow{24}{*}{$\begin{array}{l}\text { General } \\
\text { Interior }\end{array}$} & \multirow{5}{*}{ Pencahayaan } & Sangat baik & 95 \\
\hline & & Baik & 340 \\
\hline & & Cukup baik & 108 \\
\hline & & Tidak baik & 32 \\
\hline & & Sangat tidak baik & 4 \\
\hline & \multicolumn{2}{|r|}{ Jumlah } & 579 \\
\hline & \multicolumn{2}{|c|}{ Rata-Rata } & 3.6 \\
\hline & \multicolumn{2}{|c|}{ Keterangan } & Cukup Baik \\
\hline & \multirow{5}{*}{ Pendingan Udara } & Sangat baik & 105 \\
\hline & & Baik & 320 \\
\hline & & Cukup baik & 150 \\
\hline & & Tidak baik & 18 \\
\hline & & Sangat tidak baik & 0 \\
\hline & \multicolumn{2}{|c|}{ Jumlah } & 593 \\
\hline & \multicolumn{2}{|c|}{ Rata-Rata } & 3.7 \\
\hline & \multicolumn{2}{|c|}{ Keterangan } & Cukup Baik \\
\hline & \multirow{5}{*}{ Kebersihan } & Sangat baik & 70 \\
\hline & & Baik & 224 \\
\hline & & Cukup baik & 213 \\
\hline & & Tidak baik & 34 \\
\hline & & Sangat tidak baik & 2 \\
\hline & \multicolumn{2}{|c|}{ Jumlah } & 543 \\
\hline & \multicolumn{2}{|c|}{ Rata-Rata } & 3.4 \\
\hline & \multicolumn{2}{|c|}{ Keterangan } & Cukup Baik \\
\hline
\end{tabular}

Dari tabel di atas dapat diketahui bahwa jumlah rata-rata responden variabel general interior pada item pencahayaan sebesar 3,6 dengan keterangan cukup baik, pada item pendingan udara memiliki skor rata-rata sebesar 3,7 dengan keterangan cukup baik, dan pada item kebersihan memiliki skor rata-rata sebesar 3,4 dengan keterangan cukup baik. 


\subsubsection{Deskripsi Variabel Store Layout $\left(\mathrm{X}_{3}\right)$}

Adapun jawaban dari responden mengenai variabel store layout (X3) dalam tabel penelitian berikut ini :

Tabel 10. Deskripsi Jawaban Responden pada Variabel Store Layout

\begin{tabular}{|c|c|c|c|}
\hline Variabel & Item & Skor & Total Jawaban \\
\hline \multirow{24}{*}{ Store Layout } & \multirow{5}{*}{ Penataan Barang } & Sangat baik & 90 \\
\hline & & Baik & 364 \\
\hline & & Cukup baik & 126 \\
\hline & & Tidak baik & 16 \\
\hline & & Sangat tidak baik & 1 \\
\hline & \multicolumn{2}{|c|}{ Jumlah } & 597 \\
\hline & \multicolumn{2}{|c|}{ Rata-Rata } & 3.7 \\
\hline & \multicolumn{2}{|c|}{ Keterangan } & Cukup Baik \\
\hline & \multirow{5}{*}{ Jenis Pakaian } & Sangat baik & 75 \\
\hline & & Baik & 324 \\
\hline & & Cukup baik & 144 \\
\hline & & Tidak baik & 22 \\
\hline & & Sangat tidak baik & 5 \\
\hline & \multicolumn{2}{|c|}{ Jumlah } & 570 \\
\hline & \multicolumn{2}{|c|}{ Rata-Rata } & 3.6 \\
\hline & \multicolumn{2}{|c|}{ Keterangan } & Cukup Baik \\
\hline & \multirow{5}{*}{ Fasilitas Toko } & Sangat baik & 65 \\
\hline & & Baik & 276 \\
\hline & & Cukup baik & 159 \\
\hline & & Tidak baik & 42 \\
\hline & & Sangat tidak baik & 4 \\
\hline & \multicolumn{2}{|c|}{ Jumlah } & 546 \\
\hline & \multicolumn{2}{|c|}{ Rata-Rata } & 3.4 \\
\hline & \multicolumn{2}{|c|}{ Keterangan } & Cukup Baik \\
\hline
\end{tabular}

Dari tabel di atas dapat diketahui bahwa jumlah rata-rata responden variabel store layout pada item penataan barang sebesar 3,7 dengan keterangan cukup baik, pada item jenis pakaian memiliki skor rata-rata sebesar 3,6 dengan keterangan cukup baik, dan pada item fasilitas toko memiliki skor rata-rata sebesar 3,4 dengan keterangan cukup baik. 


\subsubsection{Deskripsi Variabel Interior Display $\left(\mathrm{X}_{4}\right)$}

Adapun jawaban dari responden mengenai variabel interior display (X4) dalam tabel penelitian berikut ini :

Tabel 11. Deskripsi Jawaban Responden pada Variabel Interior Display

\begin{tabular}{|c|c|c|c|}
\hline Variabel & Item & Skor & Total Jawaban \\
\hline \multirow{24}{*}{$\begin{array}{l}\text { Interior } \\
\text { Display }\end{array}$} & \multirow{5}{*}{ Hiasan Dinding } & Sangat baik & 110 \\
\hline & & Baik & 336 \\
\hline & & Cukup baik & 123 \\
\hline & & Tidak baik & 20 \\
\hline & & Sangat tidak baik & 3 \\
\hline & \multicolumn{2}{|r|}{ Jumlah } & 592 \\
\hline & \multicolumn{2}{|c|}{ Rata-Rata } & 3.7 \\
\hline & \multicolumn{2}{|c|}{ Keterangan } & Cukup Baik \\
\hline & \multirow{5}{*}{ Tanda Informasi } & Sangat baik & 115 \\
\hline & & Baik & 308 \\
\hline & & Cukup baik & 138 \\
\hline & & Tidak baik & 28 \\
\hline & & Sangat tidak baik & 0 \\
\hline & \multicolumn{2}{|c|}{ Jumlah } & 589 \\
\hline & \multicolumn{2}{|c|}{ Rata-Rata } & 3.7 \\
\hline & \multicolumn{2}{|c|}{ Keterangan } & Cukup Baik \\
\hline & \multirow{5}{*}{$\begin{array}{c}\text { Media } \\
\text { Pembungkus }\end{array}$} & Sangat baik & 120 \\
\hline & & Baik & 328 \\
\hline & & Cukup baik & 117 \\
\hline & & Tidak baik & 28 \\
\hline & & Sangat tidak baik & 1 \\
\hline & \multicolumn{2}{|c|}{ Jumlah } & 594 \\
\hline & \multicolumn{2}{|c|}{ Rata-Rata } & 3.7 \\
\hline & \multicolumn{2}{|c|}{ Keterangan } & Cukup Baik \\
\hline
\end{tabular}

Dari tabel di atas dapat diketahui bahwa jumlah rata-rata responden variabel interior display pada item hiasan dinding memiliki skor sebesar 3,7 dengan keterangan cukup baik, pada item tanda informasi memiliki skor rata-rata sebesar 3,7 dengan keterangan cukup baik, dan ada item media pembungkus memiliki skor rata-rata sebesar 3,7 dengan keterangan cukup baik. 


\subsubsection{Deskripsi Variabel Minat Beli (Y)}

Adapun jawaban dari responden mengenai variabel minat beli (Y) dalam tabel penelitian berikut ini :

Tabel 12. Deskripsi Jawaban Responden pada Variabel Minat Beli

\begin{tabular}{|c|c|c|c|}
\hline Variabel & Item & Skor & Total Jawaban \\
\hline \multirow{32}{*}{ Minat Beli } & \multirow{5}{*}{ Attention } & Sangat baik & 115 \\
\hline & & Baik & 240 \\
\hline & & Cukup baik & 153 \\
\hline & & Tidak baik & 42 \\
\hline & & Sangat tidak baik & 5 \\
\hline & \multicolumn{2}{|c|}{ Jumlah } & 555 \\
\hline & \multicolumn{2}{|c|}{ Rata-Rata } & 3.5 \\
\hline & \multicolumn{2}{|c|}{ Keterangan } & Cukup Baik \\
\hline & \multirow{5}{*}{ Interest } & Sangat baik & 90 \\
\hline & & Baik & 340 \\
\hline & & Cukup baik & 120 \\
\hline & & Tidak baik & 34 \\
\hline & & Sangat tidak baik & 0 \\
\hline & \multicolumn{2}{|c|}{ Jumlah } & 584 \\
\hline & \multicolumn{2}{|c|}{ Rata-Rata } & 3.7 \\
\hline & \multicolumn{2}{|c|}{ Keterangan } & Cukup Baik \\
\hline & \multirow{5}{*}{ Desire } & Sangat baik & 90 \\
\hline & & Baik & 316 \\
\hline & & Cukup baik & 150 \\
\hline & & Tidak baik & 26 \\
\hline & & Sangat tidak baik & 0 \\
\hline & \multicolumn{2}{|c|}{ Jumlah } & 582 \\
\hline & \multicolumn{2}{|c|}{ Rata-Rata } & 3.6 \\
\hline & \multicolumn{2}{|c|}{ Keterangan } & Cukup Baik \\
\hline & \multirow{5}{*}{ Action } & Sangat baik & 120 \\
\hline & & Baik & 284 \\
\hline & & Cukup baik & 126 \\
\hline & & Tidak baik & 42 \\
\hline & & Sangat tidak baik & 2 \\
\hline & \multicolumn{2}{|c|}{ Jumlah } & 574 \\
\hline & \multicolumn{2}{|c|}{ Rata-Rata } & 3.6 \\
\hline & \multicolumn{2}{|c|}{ Keterangan } & Cukup Baik \\
\hline
\end{tabular}

Dari tabel di atas dapat diketahui bahwa jumlah rat-rata responden variabel minat beli pada item attention memiliki skor sebesar 3,5 dengan keterangan cukup baik, pada item interest memiliki skor rata-rata sebesar 3,7 dengan keterangan cukup baik sangat baik, pada item desire memiliki skor rata-rata sebesar 3,6 dengan keterangan cukup baik, dan pada item actionmemiliki skor rata-rata sebesar 3,6 dengan keterangan cukup baik.

\subsection{Uji Asumsi Klasik}

Tahap selanjutnya dalam analisis data adalah melakukan uji asumsi klasik. Uji asumsi klasik ini dilakukan karena merupakan syarat yang harus dilakukan dalam pengujian dengan menggunakan teknik analisis regresi berganda. Adapun uji asumsi klasik yang dilakukan dalam penelitian ini meliputi uji normalitas data, uji multikolinieritas, uji heteroskedastisitas dan uji Autokorelasi. Hasil-hasil pengujian asumsi klasik tersebut akan diuraikan di bawah ini. 


\subsubsection{Uji Normalitas}

Uji normalitas data dilakukan untuk mengetahui apakah data yang diperoleh dalam penelitian ini berdistribusi normal karena dalam penggunaaan teknik analisis regresi berganda mensyaratkan data yang berdistribusi normal. Pengujian normalitas data dalam penelitian ini dilakukan dengan menggunakan rasio skewness dan rasio kurtosis. Hasil uji normalitas data disajikan dalam gambar berikut ini.

Tabel 13. Hasil Uji Normalitas

Descriptive Statistics

\begin{tabular}{|l|r|r|r|r|}
\hline \multirow{2}{*}{} & \multicolumn{2}{|c|}{ Skewness } & \multicolumn{2}{c|}{ Kurtosis } \\
\cline { 2 - 5 } & \multicolumn{1}{|c|}{ Statistic } & Std. Error & Statistic & Std. Error \\
\hline $\begin{array}{l}\text { Unstandardized Residual } \\
\text { Valid N (listwise) }\end{array}$ & -.146 & .192 & -.596 & .381 \\
\hline
\end{tabular}

Dari tabel di atas terlihat bahwa rasio skewness $=-0,146 / 0,192=-0,760$, sedangkan rasio kurtosis $=-0,596 / 0,381=-1,564$. Karena rasio skewness dan rasio kurtosis berada di antara -2 hingga +2 , maka dapat disumpulkan bahwa distribusi data adalah normal.

\subsubsection{Uji Multikolinearitas}

Uji asumsi klasik selanjutnya yang dilakukan dalam penelitian ini adalah uji multikolinieritas. Pengujian ini bertujuan untuk mengetahui apakah variabel independen saling berhubungan secara linier atau tidak. Jika di antara variabel-variabel independen yang digunakan sama sekali tidak berhubungan satu dengan yang lain, maka dapat dikatakan bahwa tidak terjadi multikolinieritas. Pengujian multikolineritas dilaksanakan dengan menggunakan VIF dan Tolerance. Hasil analisis terhadap multikolinieritas dapat dilihat pada tabel di bawah ini :

Tabel 14. Hasil Uji Multikolinearitas

\begin{tabular}{|l|r|r|}
\hline \multicolumn{1}{|c|}{ Variabel } & Nilai Tolerance & \multicolumn{1}{c|}{ Nilai VIF } \\
\hline Exterior & 0,959 & 1,043 \\
\hline General Interior & 0,966 & 1,035 \\
\hline Store Layout & 0,823 & 1,215 \\
\hline Interior Display & 0,847 & 1,180 \\
\hline
\end{tabular}

Sumber : Lampiran 5

Berdasarkan data yang disajikan dalam tabel di atas menunjukkan bahwa nilai VIF masingmasing variabel penelitian < 10 dan nilai Tolerance masing-masing variabel lebih dari 0,1 sehingga dapat disimpulkan bahwa dalam model regresi tidak terjadi multikolinieritas.

\subsubsection{Uji Heterokedastisitas}

Uji heteroskedastisitas ini dilakukan untuk mengetahui variasi residual antar pengamatan. Hal ini perlu dilakukan karena dalam pengujian dengan menggunakan uji regresi berganda menghendaki agar variasi residual antar pengamatan adalah homogen. Dalam penelitian ini menggunakan uji glejser. Uji Glejser dilakukan dengan cara meregresikan antara variabel independen dengan nilai absolut residualnya. Jika nilai signifikansi antara variabel independen dengan absolut residual lebih dari 0,05 maka tidak terjadi masalah heteroskedastisitas. Hasil pengujian heteroskedastisitas disajikan dalam tabel berikut ini : 
Tabel 15. Hasil Uji Heterokedastisitas

Coefficients ${ }^{\mathrm{a}}$

\begin{tabular}{|c|c|c|c|c|c|c|}
\hline & & \multicolumn{2}{|c|}{$\begin{array}{l}\text { Unstandardized } \\
\text { Coefficients }\end{array}$} & \begin{tabular}{|c|} 
Standardized \\
Coefficients \\
\end{tabular} & \multirow[b]{2}{*}{$\mathrm{T}$} & \multirow[b]{2}{*}{ Sig. } \\
\hline \multicolumn{2}{|c|}{ Model } & B & Std. Error & Beta & & \\
\hline 1 & (Constant) & 1.792 & .889 & & 2.016 & .045 \\
\hline & $\mathrm{X} 1$ & -.019 & .054 & -.028 & -.356 & .723 \\
\hline & $\mathrm{X} 2$ & .089 & .053 & .132 & 1.685 & .094 \\
\hline & X3 & -.157 & .048 & -.280 & -.301 & .758 \\
\hline & $\mathrm{X} 4$ & .062 & .053 & .099 & 1.179 & .240 \\
\hline
\end{tabular}

a. Dependent Variable: abresid

Pada tabel di atas terlihat bahwa nilai signifikansi ke empat variabel independen lebih dari 0,05. Dengan demikian dapat disimpulkan bahwa tidak terjadi masalah heteroskedastisitas pada model regresi.

\subsubsection{Uji Autokorelasi}

Uji Autokorelasi digunakan untuk menguji apakah dalam sebuah model regresi linier terdapat korelasi antara kesalahan pengganggu pada periode $\mathrm{t}$ dengan kesalahan pada periode $\mathrm{t}-1$ (sebelumnya). Untuk menguji Autokorelasi dapat dilihat dari nilai Durbin Waston (DW). Tabel berikut menunjukkan hasil uji autokolrelasi, yaitu :

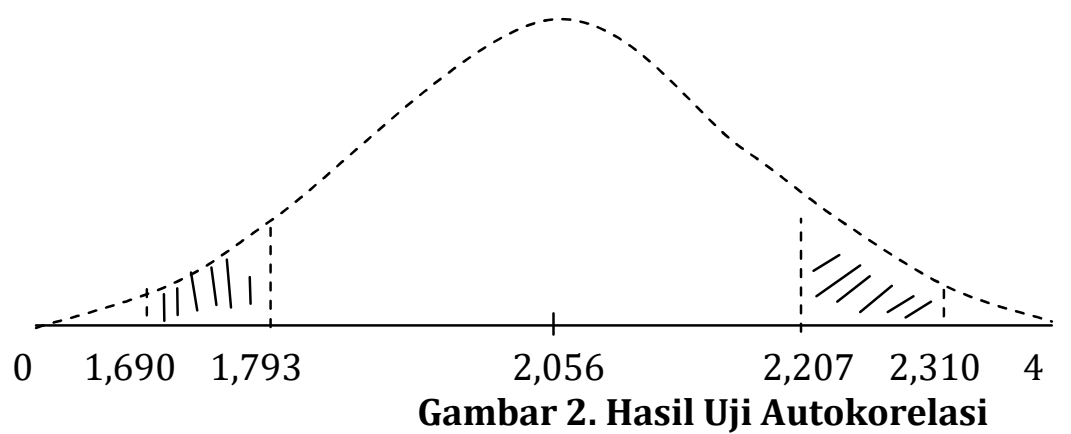

Berdasarkan gambar di atas menunjukkan bahwa nila Durbin Watson (DW) sebesar 2,056, nilai dU sebesar 1,793 dan nilai dL sebesar 1,690. Hal ini menunjukkan bahwa tidak terjadi autokorelasi karena dU $<$ DW $<4$-dU.

\subsection{Regresi Linier Berganda}

Metode ini digunakan untuk mengetahui pengaruh variabel exterior, general interior, store layout, dan interior display terhadap minat beli konsumen pada distro-distro di Mataram. Proses analisis regresi berganda tersebut menggunakan bantuan program software komputer yaitu SPSS. 
Tabel 16. Hasil Analisis Regresi Linier Berganda Coefficients ${ }^{\mathbf{a}}$

\begin{tabular}{|c|c|c|c|c|c|c|c|}
\hline \multirow[b]{2}{*}{ Model } & \multicolumn{2}{|c|}{$\begin{array}{c}\text { Unstandardized } \\
\text { Coefficients }\end{array}$} & \multirow{2}{*}{\begin{tabular}{|c|c}
$\begin{array}{c}\text { Standardize } \\
\mathrm{d} \\
\text { Coefficients }\end{array}$ \\
Beta
\end{tabular}} & \multirow[b]{2}{*}{$\mathrm{t}$} & \multirow[b]{2}{*}{ Sig. } & \multicolumn{2}{|c|}{$\begin{array}{l}\text { Collinearity } \\
\text { Statistics }\end{array}$} \\
\hline & B & Std. Error & & & & Tolerance & VIF \\
\hline 1 (Constant) & 7.887 & 1.610 & & 4.898 & .000 & & \\
\hline $\mathrm{X} 1$ & .058 & .099 & .044 & .592 & .554 & .959 & 1.043 \\
\hline $\mathrm{X} 2$ & .137 & .096 & .107 & 1.427 & .156 & .966 & 1.035 \\
\hline $\mathrm{X} 3$ & .239 & .086 & .224 & 2.771 & .006 & .823 & 1.215 \\
\hline $\mathrm{X} 4$ & .275 & .096 & .229 & 2.873 & .005 & .847 & 1.180 \\
\hline
\end{tabular}

a. Dependent Variable: $Y$

berikut:

Berdasarkan tabel di atas, analisis regresi linier berganda dapat disusun persamaan sebagai

$Y=7,887+0,058 X_{1}+0,137 X_{2}+0,239 X_{3}+0,275 X_{4}$ berikut:

Maka dari hasil perhitungan yang disajikan pada tabel di atas dapat dijelaskan sebagai

a. Nilai konstanta pada persamaan tersebut sebesar 7,887 artinya bahwa apabila variabel exterior, general interior, store layout, dan interior display tidak ada, maka nilai dari variabel minat beli konsumen pada distro-distro di Mataram adalah sebesar 7,887.

b. Pengaruh variabel exterior $\left(\mathrm{X}_{1}\right)$ terhadap minat beli konsumen $(\mathrm{Y})$. Berdasarkan perhitungan dengan program SPSS, maka diperoleh nilai koefisien regresi sebesar 0,058. Artinya variabel exterior (X1) mempunyai pengaruh yang positif dan signifikan terhadap minat beli konsumen (Y) yakni sebesar 0,058.

c. Pengaruh variabel general interior $\left(\mathrm{X}_{2}\right)$ terhadap minat beli konsumen $(\mathrm{Y})$. Berdasarkan perhitungan dengan program SPSS, maka diperoleh nilai koefisien regresi sebesar 0,137. Artinya variabel general interior mempunyai pengaruh yang positif tetapi tidak signifikan yang paling kecil dari variable lainnya terhadap minat beli konsumen (Y) yaitu sebesar 0,137 .

d. Pengaruh variabel store layout $\left(\mathrm{X}_{3}\right)$ terhadap minat beli konsumen (Y). Berdasarkan perhitungan dengan program SPSS, maka diperoleh nilai koefisien regresi sebesar 0,239. Artinya variabel store layout mempunyai pengaruh positif dan signifikan yang lebih besar dari variabel lainnya terhadap minat beli konsumen $(Y)$ yakni sebesar 0,239.

e. Pengaruh variabel interior display $\left(\mathrm{X}_{4}\right)$ terhadap minat beli konsumen $(\mathrm{Y})$. Berdasarkan perhitungan dengan program SPSS, maka diperoleh nilai koefisien regresi sebesar 0,275. Artinya variabel interior display mempunyai pengaruh positif tetapi tidak signifikan yang lebih kecil dari kecil dari variabel exrerior terhadap minat beli konsumen (Y) yakni sebesar 0,275 .

\subsection{Koefisien Determinasi Berganda $\left(R^{2}\right)$}

Koefisien determinasi $\left(\mathrm{R}^{2}\right)$ pada intinya mengukur seberapa jauh kemampuan model dalam menerangkan variasi variabel independen. Dari perhitungan dengan menggunakan program SPSS diperoleh hasil sebagai berikut: 
Tabel 17. Hasil Koefisien Determinasi Berganda ( $\left.\mathbf{R}^{2}\right)$

Model Summaryb

\begin{tabular}{|l|l|r|r|r|r|}
\hline Model & $\mathrm{R}$ & $\mathrm{R}$ Square & $\begin{array}{c}\text { Adjusted R } \\
\text { Square }\end{array}$ & $\begin{array}{c}\text { Std. Error of the } \\
\text { Estimate }\end{array}$ & Durbin-Watson \\
\hline 1 & $.404 \mathrm{a}$ & .163 & .142 & 1.930 & 2.056 \\
\hline
\end{tabular}

a. Predictors: (Constant), X4, X1, X2, X3

b. Dependent Variable: $Y$

Pada tabel di atas terlihat bahwa nilai dari R Square sebesar 0,163 atau 16,3 persen artinya kemampuan variabel independen seperti exterior, general interior, store layout, dan interior display menjelaskan variabel terikat atau minat beli konsumen sebesar 16,3 persen . Sedangkan sisanya sebesar 83,7\% dijelaskan oleh variabel lain diluar variabel independen yang diteliti.

\subsection{Uji Hipotesis}

\subsubsection{Uji Parsial (Uji t)}

Uji t digunakan untuk mengetahui signifikansi atau kuat tidaknya masing-masing variabel diantaranya variabel exterior, general interior, store layout, dan interior display berpengaruh signifikansi atau tidak terhadap minat beli konsumen pada distro-distro di Mataram. Berikut hasil perhitungan $\mathrm{t}$ hitung serta tingkat signifikansi masing-masing indikator dari variabel $\mathrm{X}$ terhadap variabel Y :

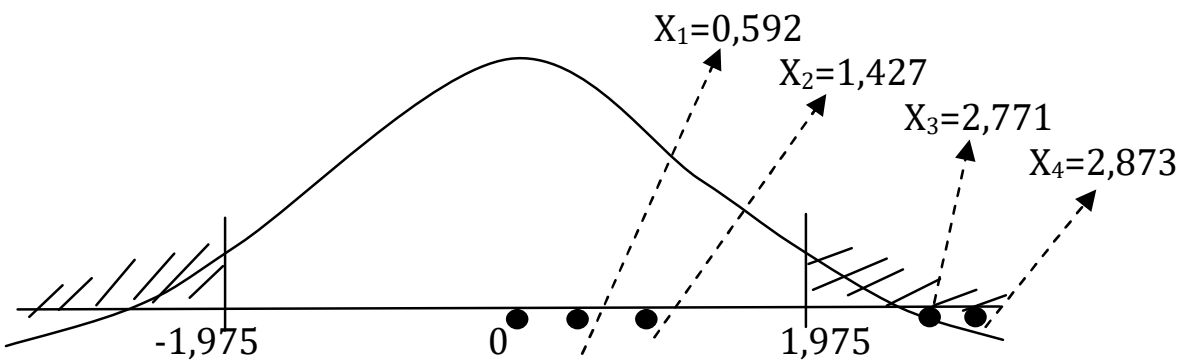

Gambar 3. Hasil Uji t

Untuk lebih jelasnya, berikut akan diuraikan makna dari hasil analisis variabel exterior, general interior, store layout, dan Interior display terhadap minat beli konsumen pada distro-distro di Mataram.

a. Variabel exterior $\left(\mathrm{X}_{1}\right)$, mempunyai nilai $\mathrm{t}$ hitung $<\mathrm{t}$ tabel yaitu $\mathrm{t}$ hitung $=0,592<\mathrm{t}$ tabel $=$ 1,975, artinya bahwa variabel exterior berpengaruh positif namun tidak signifikan terhadap minat beli konsumen pada distro-distro di Mataram. Karena nilai t tabel lebih besar dari pada nilai t hitung.

b. Variabel general interior (x2), mempunyai nilai t hitung $<\mathrm{t}$ tabel yaitu $\mathrm{t}$ hitung $=1,427<\mathrm{t}$ tabel $=1,975$, artinya bahwa variabel general interior berpengaruh positif namun tidak signifikan terhadap minat beli konsumen pada distro-distro di Mataram. Karena nilai t tabel lebih besar dari pada nilai t hitung.

c. Variabel store layout $\left(\mathrm{X}_{3}\right)$, mempunyai nilai $\mathrm{t}$ hitung $>\mathrm{t}$ tabel yaitu $\mathrm{t}$ hitung $=2,771>\mathrm{t}$ tabel $=$ 1,975 , artinya bahwa variabel store layout berpengaruh positif dan signifikan minat beli konsumen pada distro-distro di Mataram. Karena nilai t tabel lebih kecil dari pada nilai t hitung.

d. Variabel interior display $\left(\mathrm{X}_{4}\right)$, mempunyai nilai $\mathrm{t}$ hitung $>\mathrm{t}$ tabel yaitu $\mathrm{t}$ hitung $=2,873>\mathrm{t}$ tabel $=1,975$, artinya bahwa variabel interior display berpengaruh positif dan signifikan terhadap minat beli konsumen pada distro-distro di Mataram. Karena nilai t tabel lebih besar dari pada nilai thitung. 
Dari penjelasan di atas maka $\mathrm{H}_{0}$ ditolak dan $\mathrm{H}_{a}$ diterima. Artinya variabel Store Layout dan Interior Display berpengaruh positif dan signifikan terhadap minat beli konsumen pada distrodistro di Mataram.Sedangkan $\mathrm{H}_{0}$ diterima dan $\mathrm{H}_{\mathrm{a}}$ ditolak. Artinya variabel Exterior dan General Interior berpengaruh positif namun tidak signifikan terhadap variabel minat beli konsumen pada distro-distro di Mataram.

\subsubsection{Uji Simultan (Uji F)}

Uji F dilakukan untuk mengetahui tingkat signifikansi pengaruh variabel bebas yang terdiri dari exterior, general interior, store layout dan interior display terhadap variabel terikat yaitu minat beli konsumen. Berikut hasil pengujian ini dapat dilihat pada tabel bawah ini:

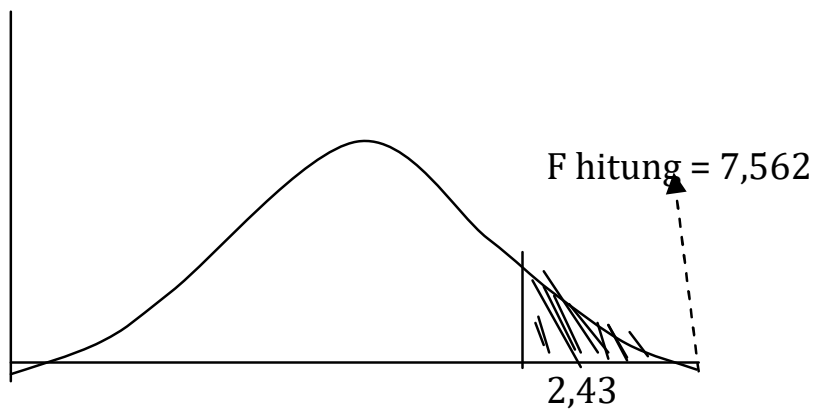

Gambar 4. Hasil Uji Simultan Model Regresi Berganda

Berdasarkan gambar di atas dapat dilihat bahwa nilai F hitung adalah 7,562. Sementara itu, pada taraf signifikansi 5\%, nilai $\mathrm{F}$ tabel diperoleh sebesar 2,43. Dengan demikian maka F hitung $>\mathrm{F}$ tabel $(7,562>2,43)$. Hal tersebut menunjukkan bahwa Ho ditolak, yang berarti bahwa variabel exterior, general interior, store layout dan interior dispay tidak memiliki pengaruh yang signifikan secara bersama-sama terhadap minat beli konsumen pada distro-distro di Mataram.

\subsubsection{Uji Dominan}

Untuk mengetahui variabel yang memiliki pengaruh paling dominan dapat dilihat pada kolom standardized coefficients Beta yaitu koefisien dari masing-masing variabel bebas. Untuk mengatahui tentang variabel yang memiliki pengaruh dominan dapat dilihat pada tabel Coefficient di bawah ini:

Tabel 18. Hasil Uji Dominan Model Regresi Berganda Coefficients ${ }^{\mathbf{a}}$

\begin{tabular}{|c|c|c|c|c|c|c|c|}
\hline \multirow[b]{2}{*}{ Model } & \multicolumn{2}{|c|}{$\begin{array}{l}\text { Unstandardized } \\
\text { Coefficients }\end{array}$} & \multirow{2}{*}{\begin{tabular}{|c|}
$\begin{array}{c}\text { Standardized } \\
\text { Coefficients }\end{array}$ \\
Beta \\
\end{tabular}} & \multirow[b]{2}{*}{$\mathrm{T}$} & \multirow[b]{2}{*}{ Sig. } & \multicolumn{2}{|c|}{$\begin{array}{l}\text { Collinearity } \\
\text { Statistics }\end{array}$} \\
\hline & B & Std. Error & & & & Tolerance & VIF \\
\hline 1 (Constant) & 7.887 & 1.610 & & 4.898 & .000 & & \\
\hline $\mathrm{X} 1$ & .058 & .099 & .044 & .592 & .554 & .959 & 1.043 \\
\hline $\mathrm{X} 2$ & .137 & .096 & .107 & 1.427 & .156 & .966 & 1.035 \\
\hline X3 & .239 & .086 & .224 & 2.771 & .006 & .823 & 1.215 \\
\hline $\mathrm{X} 4$ & .275 & .096 & .229 & 2.873 & .005 & .847 & 1.180 \\
\hline
\end{tabular}

a. Dependent Variable:

Y

Dari tabel 5.19 di atas, dapat diketahui bahwa variabel yang memiliki koefisien paling besar berdasarkan standardized coefficients Beta adalah variabel Interior Display (X4) yaitu sebesar 0,229. Dengan demikian, variabel yang memiliki pengaruh dominan terhadap minat beli konsumen pada distro-distro di Mataram adalah Interior Display. 


\subsection{Interpretasi Hasil}

Berdasarkan hasil uji t dapat dilihat bahwa tidak semua variabel independen yaitu exterior, general interior, store layput, dan interior display berpengaruh positif dan signifikan terhadap minat beli konsumen distro-distro di Mataram. Hal ini dapat dilihat pada uji t yang menyatakan t hitung masing-masing variabel store layput dan interior display $(2,771 ; 2,873)>t$ tabel $(1,975)$, serta level signifikan lebih kecil dari 0,05 masing-masing sebesar $(0,005 ; 0,006)$ dengan demikian Ho ditolak dan Ha diterima yang berarti variabel store layput dan interior displayberpengaruh signifikan terhadap minat beli konusmenpada distro-distro di Mataram. Sedangkan variabel generalinterior dan interior display $(0,592 ; 1,427)<\mathrm{t}$ tabel $(1,975)$, serta level signifikan lebih besar dari 0,05 masing-masing sebesar $(0,554 ; 0,156)$ dengan demikian Ho terima dan Ha ditolak yang berarti variabel exterior dan general interior tidak berpengaruh signifikan terhadap minat beli konsumen pada distro-distro di Mataram yang berarti semua hipotesis diterima dan ditolak.

Menurut hasil pengujian yang dapat dilihat dari tabel Coefficient kolom standardized coefficient beta tertinggi dimiliki oleh variabel Interior Display sebesar 0,229. Hal ini berarti variabel yang memiliki pengaruh dominan terhadap minat beli konsumen pada distro-distro di Mataram yaitu variabel Interior Display.Interior Display merupakan elemen yang paling vital dalam faktor store atmosphere karena elemen ini merupakankesan pertama yang dilihat dan dirasakan oleh konsumen.

Secara umum semua variabel independen pada penelitian ini berpengaruh namun tidak signifikan terhadap minat beli konsumen pada distro-distro di Mataram. Hal ini dikarenakan responden tidak begitu memperhatikan setiap variabel berkaitan dengan store atmosphere secara terpisah, karena store atmosphere itu sendiri merupakan satu kesatuan yang utuh. Dengan kata lain setiap variabel secara terpisah tidak memiliki pengaruh yang besar dalam menentukan tindakan pembelian yang dilakukan oleh responden saat melakukan pembelian.

\section{Kesimpulan dan Rekomendasi}

\subsection{Kesimpulan}

Kesimpulan dari penelitian ini adalah sebagai berikut :1) Variabel store layput dan interior displayberpengaruh signifikan terhadap minat beli konusmenpada distro-distro di Mataram. Hal ini dapat dilihat pada uji t yang menyatakan t hitung masing-masing variabel store layput dan interior display $(2,771 ; 2,873)>\mathrm{t}$ tabel $(1,975)$; 2$)$ Variabel generalexterior dan general interior tidak berpengaruh signifikan terhadap minat beli konsumen pada distro-distro di Mataram. Hal ini dapat dilihat pada uji t yang menyatakan t hitung masing-masing variabel generalinterior dan interior display $(0,592 ; 1,427)<\mathrm{t}$ tabel $(1,975)$; 3) Dari tabel Coefficient kolom standardized coefficient beta tertinggi dimiliki oleh variabel Interior Display sebesar 0,229. Hal ini berarti variabel yang memiliki pengaruh dominan terhadap minat beli konsumen pada distro-distro di Mataram yaitu variabel Interior Display. Sedangkan Coefficient kolom standardized coefficient beta terendah dimiliki oleh variabel exterior yaitu sebesar 0,044.

\subsection{Rekomendasi}

Rekomendasi yang pelu dikemukakan pada penelitian ini adalah sebagai berikut : 1) Pihak perusahaan hendaknya memperhatikan dan memperbaiki exterior (bagian luar toko) yang terdiri dari papan nama toko, desain bangunan toko dan lingkungan sekitar, memperhatikan dan memperbaiki general interior (bagian dalam toko) yang terdiri dari pencahayaan, pendinginu adara dan kebersihan, dan memperhatikan dan memperbaiki store layout (tata letak toko) yang terdiri dari penataan barang, jenis pakaian dan fasilitas toko; 2) Dari hasil penelitian, bahwa Interior Display (dekorasi pemikat dalam ruangan) memiliki pengaruh yang paling dominan terhadap minat beli konsumen pada distro-distro di Mataram sehinggan harus lebih menarik lagi. 


\section{Daftar Pustaka}

Alma, B. (2011). Pemasaran dan Pemasaran Jasa. In Pemasaran dan Pemasaran Jasa.

Gillani, F. (2012). Impact of Peer Pressure and Store Atmosphere on Purchase Intention: An Empirical Study on the Youngsters in Pakistan. International Journal of Academic Research in Business and Social Sciences.

Meldarianda, R., \& Lisan S, H. (2010). Pengaruh Store Atmosphere Terhadap Minat Beli Konsumen Pada Resort Café Atmosphere Bandung. Jurnal Bisnis Dan Ekonomi (JBE).

Sugiyono, P. D. (2010). Metode Penelitian Bisnis. Pendekatan Kuantitatif, kualitatif dan R \& D. In Bandung: Alfabeta. 